\title{
Od ceremoniału papieskiego do ceremoniału biskupiego. Wpływ renesansowej Cappella Papale na liturgiczny rytm życia stolic biskupich
}

\author{
Bartłomiej Krzysztof Krzych \\ Uniwersytet Rzeszowski \\ bartlomiejkk@gmail.com (D) http://orcid.org/0000-0003-2525-9759
}

Liturgia i zwyczaje dworu papieskiego, które zostały skodyfikowane w formie ceremoniału na przełomie XV i XVI wieku, wywarły znaczący wpływ na codzienne życie stolic biskupich w całym chrześcijańskim świecie. Toczyło się ono w rytm roku kościelnego i sprawowanych codziennie liturgii (przede wszystkim msza święta oraz oficjum).

Do dziś głównym źródłem i podstawą liturgii pontyfikalnych jest pontyfikał (Pontificale Romanum) oraz właśnie ceremoniał biskupi (Caeremoniale Episcoporum). O ile ten pierwszy jest pełnoprawną księgą liturgiczną zawierającą obrzędy (nigryki i rubryki) nadzwyczajnych celebracji związanych z posługą pasterską biskupa (święcenia, konsekracje, etc.), o tyle drugi to księga opisująca wyłącznie ceremonie (dla liturgii całego roku liturgicznego) oraz elementy etykiety przestrzeganej na dawniejszych dworach biskupich, w katedrach i kolegiatach. Przedstawia zatem ich życie codzienne - od wyboru biskupa, przez uroczystości roku kościelnego, po szczegółowe funkcje ministrów.

Ceremoniał biskupi wydany po raz pierwszy w roku 1600 (na polecenie ojców Soboru Trydenckiego) jest w rzeczywistości, jak wskazują badacze i przywoływani dalej znawcy liturgii, dostosowanym do realiów katedralnych ceremoniałem papieskim (Caeremoniale Romanum lub Caeremoniale Apostolicum). Ceremoniał ten był dziełem tzw. wielkich 
mistrzów papieskich ceremonii: Agostina Piccolominiego ${ }^{1}$, Joannesa Burcharda $^{2}$, Paride’a Grassiego ${ }^{3}$ ). Okazuje się więc, że liturgia rzymska (zwłaszcza w formie pontyfikalnej, ale również w parafialnym wymiarze) przynajmniej do początku drugiej połowy XX wieku była skodyfikowana w papieskim ceremoniale, rozprzestrzeniając się na cały świat katolicki.

Celem tekstu jest omówienie związków ceremoniału biskupiego i ceremoniału papieskiego, zależności między nimi oraz wskazanie kluczowych elementów konstytuujących liturgiczną praxis kościołów katedralnych. Przedstawione zostaną następujące zagadnienia: (1) uwagi wstępne wyjaśniające historyczny i aktualny stan liturgicznej praktyki w Kościele rzymskim; (2) liturgia papieska w historii; (3) znaczenie i wpływ liturgii papieskiej na rozwój rytu rzymskiego (liturgii pontyfikalnej); (4) najważniejsze elementy z historii ceremoniału papieskiego; (5) dzieje powstania i źródła opracowania ceremoniału biskupiego; (6) podsumowanie.

\section{Caeremoniale Episcoporum oraz liturgia pontyfikalna dawniej i dziś - uwagi wstępne}

W pierwszej kolejności należy sformułować kilka ogólnych uwag odnośnie do liturgii pontyfikalnej (szczególnie ceremoniału biskupiego), zwłaszcza w kontekście generalnej reformy liturgicznej ubiegłego wieku dokonanej z polecenia II Soboru Watykańskiego, a także odnośnie

1 Lata życia: 1435-1495. Zob. N. M. Helmy, Patrizi Piccolomini, Agostino, [w:] Dizionario Biografico degli Italiani, http://www.treccani.it/enciclopedia/agostino-patrizi-piccolomini_(Dizionario-Biografico) (05.01.2019).

2 Lata życia: około 1450-1506. Zob. I. Walter, Burckard, Johannes, [w:] Dizionario Biografico degli Italiani, http://www.treccani.it/enciclopedia/johannes-burckard_(DizionarioBiografico) (05.01.2019).

3 Lata życia: 1470-1528. Zob. M. Ceresa, Grassi, Paride, [w:] Dizionario Biografico degli Italiani, http://www.treccani.it/enciclopedia/paride-grassi_(Dizionario-Biografico) (05.01.2019). 
do źródeł kodyfikacji ceremoniału ${ }^{4}$. Trzeba też zaznaczyć, że literatura (zarówno historyczna i liturgiczna) jest względnie uboga, przede wszystkim w porównaniu z tym, ile się pisze na temat ksiąg liturgicznych (mam na myśli głównie rytuał, pontyfikał i mszał), zaś publikowane prace dotyczą najczęściej partykularnych kwestii (np. ciemnych jutrzni) ${ }^{5}$.

Zatem należy mieć na uwadze, że

1. Caeremoniale Episcoporum z 1600 roku to - jak wskazują autorzy ${ }^{6}$ całkowicie nowa księga (tj. taka, która w swym układzie, formie i treści jest wyjątkowa), wbrew temu, co mówi oryginalny tytuł (o księdze odnowionej) i bulla promulgacyjna ${ }^{7}$.

2. Caeremoniale Episcoporum nie jest wyłącznie kopią istniejącego wcześniej Caeremoniale Romanum (Caeremoniale Romanum nie było jedynym źródłem Caeremoniale Episcoporum ${ }^{8}$ ), ale wiernie zachowuje i oddaje jego ducha, co widać w szczegółowych rozwiązaniach (strój kanoników parati, asystencja biskupa przy mszach sprawowanych przez kanoników, cyrkuły, poszczególne ryty, np. ogłaszanie dat najważniejszych świąt kościelnych etc.).

3. Podstawową formą życia liturgicznego nie jest msza kapłana (dzisiaj powiedzielibyśmy „msza parafialna”), ale msza i liturgia wspólnotowa biskupa miejsca. Błędne jest więc rozumienie mszy

4 Z konieczności są one skrótowe i niepoparte solidną argumentacją historyczną i porównawczą „przedsoborowego” i „posoborowego” Caeremoniale Episcoporum (już samo porównanie spisów treści obu ceremoniałów zasługuje na osobne opracowanie).

5 Z polskiej literatury, jeśli chodzi o tzw. posoborową reformę, należy wspomnieć prace Jerzego Stefańskiego: J. Stefański, Caeremoniale Episcoporum. Konspekt historyczny, [w:] Ku liturgii nadziei. Księdzu dr. Bolesławowi Margańskiemu w sześćdziesiąta piąta rocznicę urodzin, red. R. Biel, Tarnów 2005, s. 387-403; tenże, Caeremoniale Episcoporum z roku 1984. Prezentacja księgi, „Liturgia Sacra” 2006 nr 12, s. 223-236; tenże, Edycja typiczna Caeremoniale Episcoporum z roku 1984. Prace redakcyjne, [w:] Ty jesteś kapłanem na wieki, red. Z. Kroplewski, A. Offmański, Szczecin 2006, s. 267-296.

6 Zob. dalsze paragrafy i bibliografia.

7 Tytuł brzmi: Caeremoniale episcoporum iussu Clementis VIII Pontificis Maximi novissime reformatum. W bulli pojawiają się również stwierdzenia o księdze zreformowanej (reformatum) - korzystam z wersji zdigitalizowanych dostępnych w internetowych bazach. Dokładnie sprawę tę wyjaśnia L. Gromier, Commentaire au Caeremoniale Episcoporum, Paris 1959, s. 7-13.

8 Zob. dalsze paragrafy. 
pontyfikalnej ${ }^{9}$ jako rozbudowanej i podstawowej formy mszy kapłana. To msza biskupa jest formą podstawową, zaś pozostałe jej odmiany (uroczysta z diakonem i subdiakonem, śpiewana, cicha, etc. ${ }^{10}$ ) są jej formami uboższymi ${ }^{11}$.

4. Wydany po II Soborze Watykańskim Caeremoniale Episcoporum (1984) stanowi zerwanie pewnej ciągłości, jakkolwiek pewne zmiany wydawały się konieczne, zwłaszcza biorąc pod uwagę kwestie pastoralne i przedrenesansową liturgię papieską (Mikołaj V, 1447-1455) ${ }^{12}$. Widać to nie tylko w przeorganizowaniu układu, ale i diametralnej zmianie treści (przykładowo kilkustronicowy rozdział poświęcony ceremoniarzowi biskupiemu zamienił się w trzyparagrafowy podrozdział ${ }^{13}$ ). Zmiany widać również w praktyce: dzisiejsza msza biskupa nie różni się praktycznie niczym od mszy kapłana (poza specyficznymi elementami związanymi z osobą biskupa, jak mitra, pastorał i piuska; wiele przepisów pozostaje też martwych, np. mówiące o ubieraniu przez biskupa dalmatyki i tuniki pod ornat lub o używaniu tzw. wielkiej kapy).

5. O sukcesie Caeremoniale Episcoporum, o którym wspominają badacze, świadczy liczba edycji wydanych w ciągu mniej więcej 350 lat: ponad 41 (Rzym - 13, Wenecja - 5, Taurini - 6, Paryż - 6, Malines -4 , Ratyzbona -3 , pozostałe miejsca -5$)^{14}$.

9 Warto zauważyć, że termin „msza pontyfikalna” (missa pontificalis) jest nieobecny w Caeremoniale Episcoporum wydanym po II Soborze Watykańskim w 1984 roku jako editio princeps. Ceremoniał ten używa określenia „msza stacyjna biskupa diecezjalnego” (missa stationalis Episcopi dioecesani).

10 Są to określenia odnoszące się do tzw. nadzwyczajnej formy rytu rzymskiego, a więc liturgii sprawowanej według ksiąg sprzed II Soboru Watykańskiego.

11 Zob. J. Nabuco, La liturgie papale et les origines du Cérémonial des Évêques, [w:] Miscellanea liturgica in honorem L. Cuniberti Mohlberg, t. 1, Romae 1948, s. 283-284.

12 J. Nabuco, F. Tamburini, Le cérémonial apostolique avant Innocent VIII. Texte du manuscrit Urbinate Latin 469 de la Bibliothèque Vaticane, Roma 1966.

13 „Przedsoborowe” Caeremoniale Episcoporum - księga 1, rozdział 5, „posoborowe” Caeremoniale Episcoporum - część 1, rozdział 2, paragrafy 34-36.

14 J. Nabuco, Ius Pontificalium. Introductio in Caeremoniale Episcoporum, Paris 1956, s. XI-XVII. Zob. Ccremoniale Episcoporum, http://caeremonialeepiscoporum.blogspot. com/p/editiones.html (03.01.2018). 
6. Obecne realia życia stolic biskupich znacznie różnią się od tych z wieków od XVII do XX, gdy istniał nie dom, ale dwór papieski ${ }^{15}$, zaś każdy z biskupów posiadał własne tzw. rodzinę i świtę - każdy ich członek miał dane funkcje do wypełnienia i określone miejsce $\mathrm{w}$ liturgicznym orszaku ${ }^{16}$.

Już kilka pobieżnych informacji pozwala zrozumieć z jednej strony doniosłość historyczną ostatnich kilkudziesięciu lat dla liturgii biskupiej i jej ceremonialnego kształtu, z drugiej - co ważniejsze - znaczenie liturgii papieskiej dla rozwoju chrześcijańskiego (katolickiego) kultu, zwłaszcza w obrębie rytu rzymskiego.

\section{Historia liturgii papieskiej (do czasów renesansu) ${ }^{17}$}

Spojrzenie na początkowe etapy i wpływy (a raczej ich brak) liturgii papieskiej na kult chrześcijański pozwala należycie zorientować się w przełomie, który dokonał się pomiędzy wiekami XIV i XV, a którego owocem było pierwsze wydanie Caeremoniale Episcoporum z 1600 roku, co wiązało się z kontrreformacyjną reakcją w postaci Soboru Trydenckiego (1545-1563), który nakazał kodyfikację ksiąg liturgicznych dla całego Kościoła ${ }^{18}$.

Do XII wieku liturgia sprawowana przez biskupa Rzymu nie różniła się zasadniczo od liturgii sprawowanych w innych stolicach biskupich (publikowane od około VII wieku tzw. Ordines Romani, mimo iż wspominały bezpośrednio o papieżu, zawierały uwagi ogólne dotyczące

15 Zob. Paweł VI, List apostolski w formie motu proprio Pontificalis Domus, 28 marca 1968. Szczegóły dla liturgii papieskiej: B. K. Krzych, Historia, źródła i ceremonie Mszy papieskiej według usus antiquior, „Christianitas” $2013 \mathrm{nr}$ 52, s. 178-212.

17 Szersze omówienie tej kwestii w: B. K. Krzych, Historia, źródła i ceremonie Mszy papieskiej, dz. cyt., s. 180-185.

18 Zob. P. Milcarek, Historia Mszy. Przewodnik po dziejach liturgii rzymskiej, Warszawa 2009, s. 58-80; J. Gręźlikowski, Trydencka reforma i odnowa Kościoła. Refleksje w 450. rocznicę od zakończenia obrad Soboru Trydenckiego (1545-1563), „Studia Włocławskie” 16 (2014), s. 126-146. 
liturgii pontyfikalnej jako takiej) ${ }^{19}$. Nawet liturgia stacyjna nie była „wyłączną własnością” Rzymu ${ }^{20}$ - odbywała się również np. w Ziemi Świętej ${ }^{21}$. Do XII wieku, kiedy to zaczęły pojawiać się specyficzne i wyraźnie odrębne elementy ceremonialne związane z osobą i godnością papieską, liturgia biskupa Rzymu miała charakter lokalny i jakkolwiek Rzym z jego biskupem byli uważani za serce chrześcijaństwa (prymat), to liturgia papieska nie miała statusu normatywnej ${ }^{22}$. Dopiero od XIII wieku Ordines Romani stają się coraz bardziej szczegółowe i dotyczą obrzędów i ceremonii związanych bezpośrednio z osobą papieża, jak np. konklawe i koronacja ${ }^{23}$.

Przełom nastąpił w XV wieku, zaś jego symbolem stał się ceremoniał rzymski (apostolski) Agostina Patriziego Piccolominiego, który stanowił zwieńczenie procesu kodyfikacji zapoczątkowanego w XIII wieku, poprzez ceremoniały awiniońskie, po powrót do Rzymu i ceremoniał Piotra Ameliusa ${ }^{24}$.

19 F. Cabrol, La liturgie et les papes, [w:] Tu es Petrus. Encyclopédie populaire sur la papauté, publiée sous la direction de G. Jacquemet, Paris 1934, s. 276. Por. B. K. Krzych, Historia, źródła i ceremonie Mszy papieskiej, dz. cyt., s. 181.

20 Zob. J. Mieczkowski, Rzymska liturgia stacyjna, „Ruch Biblijny i Liturgiczny” 65 (2012) nr 1, s. 29-44, https://doi.org/10.21906/rbl.81.

21 W szerszym i nieco późniejszym kontekście zob. R. Salvarini, Il modello gerosolimitano: continuità e transformazione nella liturgia di Gerusalemme, [w:] Liturgie e culture tra l'età di Gregorio Magno e il pontificato di Leone III. Aspetti rituali, ecclesiologici e istituzionali. Atti del Convegno, Università Europea di Roma, 24 e 25 febbraio 2011, a cura di R. Salvarini, Città del Vaticano 2011, s. 37-55.

22 F. Cabrol, La liturgie et les papes, dz. cyt., s. 277. Por. B. K. Krzych, Historia, źródła i ceremonie Mszy papieskiej, dz. cyt., s. 181.

23 F. Cabrol, La liturgie et les papes, dz. cyt., s. 280. Por. B. K. Krzych, Historia, źródła i ceremonie Mszy papieskiej, dz. cyt., s. 182.

24 Wszystkie te teksty zebrał i krytycznie opracował Marc Dykmans w dwóch seriach: M. Dykmans, Le Cérémonial papal de la fin du Moyen Âge à la Renaissance, t. 1-4, Bruxelles 1977-1985; tenże, L'oeuvre de Patrizi Piccolomini ou le cérémonial papal de la première Renaissance, t. 1-2, Città del Vaticano 1980-1982. Szczegółowe przedstawienie poszczególnych tomów oraz dalsza bibliografia: B. K. Krzych, Wstępny zestaw literatury źródłowej do badań nad liturgia papieską, „Liturgia Sacra” 17 (2011) nr 2, s. 333-347. 


\section{Znaczenie liturgii papieskiej i jej wpływ}

na liturgię biskupią (Caeremoniale Episcoporum) ${ }^{25}$

Zdaniem Joachima Nabuco, najwybitniejszego znawcy liturgii papieskiej i pontyfikalnej ubiegłego wieku oraz autora najważniejszych prac dotyczących tej tematyki, Caeremoniale Episcoporum jest przystosowaniem ceremoniału papieskiego do liturgii i warunków panujących w kościołach katedralnych i kolegiackich. W artykule poświęconym bezpośrednio tej kwestii analizuje on wpływ ceremonii dworu papieskiego i liturgii wielkich mistrzów ceremonii apostolskich na redakcję Caeremoniale Episcoporum i liturgię sprawowaną w stolicach biskupich po Soborze Trydenckim ${ }^{26}$. Wnioski Nabuco są następujące:

1. Caeremoniale Episcoporum okazał się dużym sukcesem, poza pewnymi wyjątkami został bowiem zaadaptowany w całym Kościele rzymskokatolickim;

2. Caeremoniale Episcoporum jest owocem i przekazicielem liturgii papieskiej z końca XV i początku XVI wieku, której kształt w znacznej mierze nadali tzw. wielcy mistrzowie ceremonii papieskich (Piccolomini, Burchard, Grassi) $^{27}$.

Punkty te zamykają część, w której zebrane zostały ogólne uwagi dotyczące liturgii papieskiej i jej wpływu na liturgię stolic biskupich za pośrednictwem Caeremoniale Episcoporum. Należy teraz bliżej przyjrzeć się historii Caeremoniale Romanum i Caeremoniale Episcoporum, zwłaszcza w kontekście powstania tego drugiego.

\section{Historia Caeremoniale Romanum ${ }^{28}$}

Historię powstania właściwego Caeremoniale Romanum, tzn. tego, który był w użytku od XV wieku (księga Piccolominiego) do reform litur-

25 Por. B. K. Krzych, Historia, źródła i ceremonie Mszy papieskiej, dz. cyt., s. 186-187.

26 J. Nabuco, La liturgie papale et les origines du Cérémonial des Évêques, dz. cyt.

27 Tamże, s. 300.

28 Por. B. K. Krzych, History and Meaning of the Papal Ceremonial in the History of the Liturgy, „Caeremoniale Romanum Bulletin” 2011 nr 2, s. 3-16. 
gicznych przeprowadzonych w $\mathrm{XX}$ wieku ${ }^{29}$, można podzielić na trzy zasadnicze okresy:

1. okres formowania (XII-XIV wiek);

2. okres przełomu (koniec XV i początek XVI wieku);

3. okres stabilizacji (XVI-XIX wiek).

Za pierwszy ceremoniał papieski w ścisłym znaczeniu można uznać Ordo Romanus XIII (według numeracji Jeana Mabillona) znany pod nazwą Ceremoniału rzymskiego Grzegorza $X$ (pontyfikat w latach 1271-1276), który został wydany po Soborze w Lyonie (1273). Zawierał on opisy elementów charakteryzujących liturgię apostolską (wybór i koronacja papieża, celebracje w roku liturgicznym etc.). Z późniejszych ceremoniałów należy wymienić księgę kardynała Jacopo Stefaneschiego z 1341 roku (Ordinarium Sanctae Romanae Ecclesiae, zawierało m.in. obrzędy wyboru i koronacji biskupa Rzymu, obrzędy soboru, obrzędy kanonizacji i koronacji władców), które było poszerzane w czasie pontyfikatów następnych papieży (Benedykt XII, Klemens VI, Urban V) w latach 1334-1370. Kolejny ceremoniał opracował w czasie pontyfikatu Urbana VI (1378-1389) Pierre Amelius (Caeremoniale romanum pontificium). Księga ta była w użytku również w czasie niewoli awiniońskiej, równolegle ze spisywanymi wtedy ceremoniałami, których opracowanie wymuszała sytuacja, a także wprowadzanie zastanych elementów ceremoniału liturgicznego i dworskiego na dwór papieski.

Ceremoniał Piccolominiego (De caeremoniis Curiae Romanae) został opracowany w 1488 roku (wcześniej Petrus z Burgos stworzył Caeremoniale Romanum w 1455 roku). Do jego powstania przyczynili się Burchard i Grassi (wykorzystano m.in. notatki sporządzone przez nich w dziennikach). Księga powstała z polecenia Innocentego VIII (1484-1492). Ten sam ceremoniał został wydany i - nie bez sprzeciwu i kontrowersji, co wiązało się z tradycją świętego sekretu ${ }^{30}$ - upublicz-

29 Zob. A. Bugnini, The Reform of the Liturgy 1948-1975, Collegeville 1990, s. 805-817 (rozdział o reformie tzw. kaplic papieskich czyli de facto liturgii papieskiej).

30 J. Nabuco, F. Tamburini, Cérémonial Apostolique avant Innocent VIII..., dz. cyt., dodatek drugi. Szczegółowo historię opublikowania pierwszej powszechnej wersji ceremoniału papieskiego opisuje M. Dykmans, L'oeuvre de Patrizi Piccolomini ou le cérémonial papal de la première Renaissance, dz. cyt., t. 1 , s. $27^{*}-42 *$. 
niony przez Cristofora Marcella w Wenecji w 1516 roku (Rituum ecclesiasticorum sive sacrarum ceremoniarum S.S. Romanae Ecclesiae libri tres). Był to więc pierwszy ceremoniał papieski, który nie funkcjonował wyłącznie w kręgach dworu papieskiego. Wydanie Marcellego zawierało pewne błędy, które potem trudno było wyeliminować, jednakże stało się podstawową księgą służącą do sprawowania liturgii na dworze papieskim przez następne pięć wieków (pierwsze wznowienia pojawiły się jeszcze w 1560 i 1582 roku, ostatnie zaś w czasie pontyfikatu Piusa XII).

\section{Historia powstania i źródła Caeremoniale Episcoporum}

Caeremoniale Episcoporum został promulgowany 14 lipca 1600 roku i pierwotnie składał się z dwóch ksiąg (trzecią, znacznie krótszą, dołączono później, w związku z rozwojem życia dyplomatycznego) - dokonał tego Klemens VIII bullą Cum novissime ${ }^{31}$. Jakkolwiek zawarte w Caeremoniale Episcoporum przepisy i opisy nie były nowe (opierały się wszakże na dotychczasowej tradycji i praktyce, zwłaszcza z Rzymu i okolic), sama księga - jako pełny opis ceremonii pontyfikalnych - była nowością ${ }^{32}$. Ponadto należy zaznaczyć, że Caeremoniale Episcoporum to nie drobiazgowy podręcznik ceremonii (wiele preskrypcji ma charakter ogólny lub dopuszczający pewne interpretacje), ale raczej księga podkreślająca godność biskupa, zwłaszcza otrzymaną przez niego pełnię kapłaństwa, a także władzę, które są zakorzenione w osobie,

31 A. P. M. Mutuel, P. Freeman, Notes sur les textes, [w:] Caeremoniale Episcoporum. Le Cérémonial des Éveques du concile de Trente a Vatican II. Traduction intégrale du texte selon l'édition de 1752, établie, révisée et annotée par A. P. M. Mutuel et P. Freeman, Paris 2006, s. 14. Paragraf ten w znacznej mierze opieram na tym opracowaniu. Jego nieco zmienione i skrócone fragmenty - bez podania autora - zostały umieszczone również w tym miejscu: https://www.ceremoniaire.net/office_divin/caer_ep_1/ (04.01.2019). Autorzy szeroko powołują się - również w komentarzach do poszczególnych paragrafów Caeremoniale Episcoporum - na pracę L. Gromier, Commentaire au Caeremoniale Episcoporum, dz. cyt.

32 Oprócz wcześniej przywołanej literatury zob. również: Wprowadzenie, [w:] Images de la liturgie tridentine. En 49 gravures tirées du Cérémonial des évêques, Le Barroux 2002. 
godności i władzy Najwyższego Pasterza (prymat papieski) ${ }^{33}$. Dzięki Caeremoniale Episcoporum liturgia rzymska mogła być zachowywana na całym świecie do tego stopnia, że księgę tę można określić mianem „sztandaru rzymskości”34.

Bezpośrednim impulsem dla opracowania Caeremoniale Episcoporum było powołanie komisji do prac nad ceremoniałem przez Grzegorza XIII w 1582 roku. Tworzyło ją dwóch kardynałów: Gabriele Paleotti i św. Karol Boromeusz, który wywarł znaczny wpływ na ostateczny kształt Caeremoniale Episcoporum ${ }^{35}$. Prace nad księgą przejęła Święta Kongregacja Obrzędów w 1587 roku, tuż po tym jak została utworzona. Redaktorzy, których zadaniem było przygotowanie księgi o rzymskim duchu liturgii do powszechnego użytku w Kościele (biskupstwa, klasztory, kolegiaty), niekiedy wstrzymywali się od podawania ostatecznej wersji niektórych obrzędów, głównie ze względu na ich, wtedy, status: in statu nascendi ${ }^{36}$. Źródła Caeremoniale Episcoporum były następujące ${ }^{37}$ :

1. dodatki do pontyfikałów, z których korzystano w Rzymie zanim pojawił się potrydencki Pontificale Romanum Klemensa VIII w 1596 roku;

2. Caeremoniale Romanum opracowany przez Piccolominiego (i Burcharda) w 1488 roku i późniejsze wydanie Marcello z 1516 roku;

3. w pewnej mierze diaria papieskich mistrzów ceremonii z przełomu XV i XVI wieku - jako uzupełnienie Caeremoniale Romanum;

4. praca ceremoniarza papieskiego Paride’a Grassiego z 1564 roku pt. De cœeremoniis cardinalium et episcoporum in eorum dioecesibus libro duo wydana przez Francesco Mucanzio.

33 À l'école romaine du Cérémonial des Évêques, [w:] Institut du Christ Roi Souverain Prêtre, La Messe pontificale au faldistoire, Gricigliano 2012, s. 9. Autorzy podają interesujący cytat z konstytucji Innocentego X z 30 lipca 1650 roku odnośnie do obowiązywalności Caeremoniale Episcoporum: „Caeremoniale hujusmodi... in universali Ecclesia ab omnibus... perpetuo observandum esse praecipimus...” („Nakazujemy, aby wszyscy nieprzerwanie zachowywali w ten [wierny] sposób ceremoniał”).

34 Tamże, s. 11.

35 Zob. Instructionum fabricae et supellectilis ecclesiasticae libri II Caroli Borromei, dir. scientifica S. della Torre, M. Marinelli, Città del Vaticano 2000.

36 A. P. M. Mutuel, P. Freeman, Notes sur les textes, dz. cyt., s. 14.

37 Tamże; por. L. Gromier, Commentaire au Caeremoniale Episcoporum, dz. cyt., s. 8. 
Ostatnia z wymienionych prac została przygotowana na podstawie ceremoniałów papieskich i w zasadniczych częściach jej plan oraz obfite fragmenty zaadaptowano w Caeremoniale Episcoporum. Oprócz wyżej wspomnianych uaktualnień najważniejsze miały miejsce w 1752 roku za pontyfikatu Benedykta XIV i wiązały się z rozwojem niektórych obrzędów. Wtedy też dołączono księgę trzecią z instrukcjami dla kościelnych dyplomatów ${ }^{38}$. W 1886 roku wydano ostatnią edycję typiczną Caeremoniale Episcoporum, w której zaprowadzono wiele pomniejszych zmian związanych z upadkiem życia liturgicznego w kolegiatach i postępującym rozkładem rytmu życia liturgicznego w biskupstwach - procesy te były w znacznej mierze następstwem rewolucji francuskiej ${ }^{39}$. Ostatnia edycja typiczna wiernie opisująca ceremonie pontyfikalne, a także - jak zauważają autorzy - oddająca ducha romanitas pochodzi z 1752 roku $^{40}$. Układ treści Caeremoniale Episcoporum pozostał do $\mathrm{XX}$ wieku w zasadzie niezmienny i zgody z kolejnymi etapami święceń episkopatu oraz wynikającymi z nich prerogatywami i obowiązkami (wybór, sprawowane czynności liturgiczne, rok liturgiczny, śmierć i pogrzeb biskupa $)^{\mathbf{4 1}}$.

Raz jeszcze należy podkreślić, że Caeremoniale Episcoporum to Caeremoniale Romanum przystosowany do warunków panujących w biskupstwach, kolegiatach i klasztorach. Nabuco wymienia m.in. następujące ogólne elementy, które o tym świadczą ${ }^{42}$ :

1. kapitułę (capitulum) papieża stanowi kolegium kardynałów, zaś kapitułę biskupa kolegium kanoników katedralnych;

38 A. P. M. Mutuel, P. Freeman, Notes sur les textes, dz. cyt., s. 15.

39 Tamże.

40 Tamże.

41 Dokładny spis treści można znaleźć w wersjach Caeremoniale Episcoporum dostępnych w internecie, np. w Google Books lub Archive.org.

42 J. Nabuco, La liturgie papale et les origines du Cérémonial des Évêques, dz. cyt., s. 294. Autor wskazuje również na szereg elementów, które zostały niepotrzebnie lub niepoprawnie przeniesione z liturgii papieskiej, jak np. używanie mitry w chórze bez innych szat mszalnych czy inne kwestie związane z ubiorem liturgicznym (tamże, s. 295). 
2. każdy z biskupów posiada tron (znajdujący się w kościele katedralnym), który symbolizuje jego władzę i jurysdykcję, wynikające z uniwersalnej władzy i jurysdykcji papieskiej ${ }^{43}$;

3. papież posiada swój wyłączny ołtarz (ołtarze papieskie w bazylikach większych), biskupi zaś posiadają swoje ołtarze w katedrach, jednak nie na prawach wyłączności ${ }^{44}$;

4. podobnie jak papież, biskupi również posiadają przywilej szat pontyfikalnych, z wyjątkiem kilku szat własnych biskupa Rzymu (np. fanon, mantum, pantofle z krzyżem etc.);

5. porządek mszy pontyfikalnej odpowiada w zasadzie porządkowi solennej mszy papieskiej z wyjątkiem tych elementów, które pozostały wyłącznie w liturgii papieskiej (np. komunia u tronu papieża, ryt pregustacji, śpiew czytań w językach łacińskim i greckim etc.) ${ }^{45}$.

\section{Podsumowanie}

Przedstawione - z konieczności wybiórczo i skrótowo - spostrzeżenia pozwalają stwierdzić bezpośrednią zależność Caeremoniale Episcoporum od Caeremoniale Romanum, a tym samym znaczny wpływ de facto renesansowej liturgii dworu papieskiego na liturgiczny i ceremonialny rytm życia stolic biskupich, który był - wraz z preskrypcjami pontyfikału - ,zarządzany” właśnie przez Caeremoniale Episcoporum przede wszystkim w tych aspektach, które dotyczyły osoby biskupa oraz celebracji liturgicznych w ciągu roku kościelnego. Wskazane zależności mogłyby zostać

43 Każdy biskup posiada jurysdykcję i może sprawować swą władzę na mocy łączności z biskupem Rzymu, która wynika z jednej strony z sukcesji apostolskiej, z drugiej zaś z uznania prymatu papieskiego. Tron papieski był zawsze większy niż trony biskupie (liczba stopni) oraz w większym stopniu uposażony.

44 Tzw. przywilej ołtarza papieskiego (w bazylikach papieskich tylko papież mógł odprawiać mszę świętą na głównym ołtarzu) został ograniczony przez Pawła VI w 1966 roku na mocy motu proprio Peculiare Ius, zob. B. K. Krzych, Przywilej ołtarza papieskiego, http://www.caeremonialeromanum.com/2010/05/przywilej-otarza-papieskiego.html (05.01.2019).

45 Por. B. K. Krzych, Historia, źródła i ceremonie Mszypapieskiej, dz. cyt., s. 199-200. Tekst zawiera również omówienie wszystkich ważniejszych elementów własnych liturgii papieskiej. 
szczegółowo wyartykułowane, gdyby zestawić spisy treści Caeremoniale Romanum (szczególnie Piccolominiego i Marcellego), Caeremoniale Episcoporum (pierwsze wydanie z 1600 roku) oraz źródeł, z których korzystali redaktorzy Caeremoniale Episcoporum (zwłaszcza ceremoniału Paride’a Grassiego dla kardynałów i biskupów z 1564 roku) - jest to jednak zadanie zdecydowanie przekraczające ramy niniejszego studium.

\section{Abstrakt}

\section{Od ceremoniału papieskiego do ceremoniału biskupiego. Wpływ renesansowej Cappella Papale na liturgiczny rytm życia stolic biskupich}

Głównym źródłem i podstawą liturgii pontyfikalnych jest Pontyfikał (Pontificale Romanum) i Ceremoniał Biskupi (Caeremoniale Episcoporum). O ile pierwszy z nich jest pełnoprawną księgą liturgiczną, o tyle drugi jest księgą opisującą jedynie ceremonie (dla liturgii całego roku liturgicznego) oraz elementy etykiety obowiązującej na dawnych dworach biskupich, katedrach i kolegiatach, opisując niejako ich życie codzienne (od wyboru biskupa, przez obchody roku kościelnego, po szczegółowe funkcje ministrów). Ceremoniał Biskupi, wydany po raz pierwszy w 1600 roku (na polecenie ojców Soboru Trydenckiego), jest w istocie - jak podkreślają badacze i znawcy liturgii - ceremoniałem papieskim (Caeremoniale Romanum lub Caeremoniale Apostolicum) dostosowanym do realiów katedry biskupiej. Ceremoniał ten był dziełem tzw. wielkich mistrzów ceremonii papieskich (Agostino Piccolomini, Joannes Burchard, Paride Grassi). Okazuje się, że liturgia rzymska (zwłaszcza w jej formie pontyfikalnej, ale także w wymiarze parafialnym), przynajmniej w jej kształcie do początku drugiej połowy XX wieku, została skodyfikowana w ceremoniale papieskim, rozprzestrzeniając się na cały świat katolicki. Słowa kluczowe: Caeremoniale Episcoporum, Caeremoniale Romanum, liturgia papieska, liturgia pontyfikalna

\section{Abstract}

\section{From the papal ceremonial to the episcopal ceremonial. The influence of the Renaissance Cappella Papale on the liturgical rhythm of life of episcopal sees}

The main source and basis of the pontifical liturgies is the Pontifical (Pontificale Romanum) and the Ceremonial of Bishops (Caeremoniale Episcoporum). While the 
former is a fully-fledged liturgical book, the latter is a book describing only the ceremonies (for the liturgy of the whole liturgical year) and the elements of the etiquette observed at former bishops' courts, cathedrals and collegiates, describing in a way their daily life (from the election of the bishop, through the celebrations of the church year, to the detailed functions of ministers). The Ceremonial of Bishops, published for the first time in 1600 (by order of the Fathers of the Council of Trent), is in fact, as researchers and experts in liturgy point out, a Papal Ceremonial (Caeremoniale Romanum or Caeremoniale Apostolicum) adapted to the realities of the cathedral. This ceremony was the work of the so-called great masters of papal ceremonies (Agostino Piccolomini, Joannes Burchard, Paride Grassi). It turns out that the Roman liturgy (especially in its pontifical form, but also in its parish dimension), at least in its form until the beginning of the second half of the 20th century, was codified in the papal ceremonial, spreading throughout the Catholic world.

Keywords: Caeremoniale Episcoporum, Caeremoniale Romanum, papal liturgy, pontifical liturgy

\section{References}

Bugnini, A. (1990). The reform of the liturgy 1948-1975. Liturgical Press.

Cabrol, F. (1934). La liturgie et les papes. In G. Jacquement (Ed.), Tu es Petrus. Encyclopédie populaire sur la papauté (pp. 269-291). Bloud et Gay.

Ceresa, M. (n.d.). Grassi, Paride. Dizionario Biografico Degli Italiani. Retrieved January 5, 2019, from http://www.treccani.it/enciclopedia/paride-grassi_(Dizionario-Biografico) Della Torre, S., \& Marinelli, M. (Eds.). (2000). Instructionum fabricae et supellectilis ecclesiasticae libri II Caroli Borromei. Libreria Editrice Vaticana.

Dykmans, M. (1977). Le cérémonial papal de la fin du moyen âge à la Renaissance (Vol. 1). Institut Historique Belge de Rome.

Dykmans, M. (Ed.). (1980). L’oeuvre de Patrizi Piccolomini ou le cérémonial papal de la première Renaissance. Biblioteca Apostolica Vaticana.

Dykmans, M. (1981). Le cérémonial papal de la fin du moyen âge à la Renaissance (Vol. 2). Institut Historique Belge de Rome.

Dykmans, M. (Ed.). (1982). L'oeuvre de Patrizi Piccolomini ou le cérémonial papal de la première Renaissance. Biblioteca Apostolica Vaticana.

Dykmans, M. (1983). Le cérémonial papal de la fin du moyen âge à la Renaissance (Vol. 3). Institut Historique Belge de Rome.

Dykmans, M. (1985). Le cérémonial papal de la fin du moyen âge à la Renaissance (Vol. 4). Institut Historique Belge de Rome. 
Gręźlikowski, J. (2014). Trydencka reforma i odnowa Kościoła. Refleksje w 450. Rocznicę od zakończenia obrad Soboru Trydenckiego (1545-1563). Studia Włocławskie, 16, 126-146. Gromier, L. (1957). Commentaire du caeremoniale episcoporum. La Colombe.

Helmy, N. M. (n.d.). Patrizi Piccolomini, Agostino. Dizionario Biografico Degli Italiani. Retrieved January 5, 2019, from https://www.treccani.it/enciclopedia/agostino-patrizi -piccolomini_(Dizionario-Biografico)

Images de la liturgie tridentine. En 49 gravures tirées du Cérémonial des évêques. (2002). Aux éditions Saint-Madeleine.

Krzych, B. K. (2010, May 29). Przywilej ołtarza papieskiego. http://www.caeremonialeromanum.com/2010/05/przywilej-otarza-papieskiego.html

Krzych, B. K. (2011a). History and Meaning of the Papal Ceremonial in the History of the Liturgy. Caeremoniale Romanum Bulletin, 2, 3-16.

Krzych, B. K. (2011b). Wstępny zestaw literatury źródłowej do badań nad liturgią papieską. Liturgia Sacra, 17(2), 333-347.

Krzych, B. K. (2013). Historia, źródła i ceremonie Mszy papieskiej według usus antiquior. Christianitas, 52, 178-212.

Mieczkowski, J. (2012). Rzymska liturgia stacyjna. Ruch Biblijny i Liturgiczny, 65(1), 29-44. https://doi.org/10.21906/rbl.81

Milcarek, P. (2009). Historia Mszy. Przewodnik po dziejach liturgii rzymskiej. Wydawnictwo AA, Wydawnictwo Dębogóra.

Mutel, A. P. M., \& Freeman, P. (Eds.). (2006). Caeremoniale Episcoporum. Le Cérémonial des Evêques du concile de Trente à Vatican II. Traduction intégrale du texte selon l'édition de 1752. Institut du Christ roi souverain prêtre ; Hora decima.

Nabuco, J. (1948). La liturgie papale et les origines du Cérémonial des Évêques. In Miscellanea liturgica in honorem L. Cuniberti Mohlberg (Vol. 1, pp. 283-300). Edizioni Liturgiche.

Nabuco, Joachim. (1956). Ius pontificalium. Introductio in caeremoniale episcoporum. Desclée et Socii.

Paulus PP. VI. (1968). Pontificalis Domus.

Salvarini, R. (2012). Il modello gerosolimitano: Continuità e transformazione nella liturgia di Gerusalemme. In R. Salvarani (Ed.), Liturgie e culture tra l'età di Gregorio Magno e il pontificato di Leone III. Aspetti rituali, ecclesiologici e isti-tuzionali. Atti del Convegno, Università Europea di Roma, 24 e 25 febbraio 2011 (pp. 37-55). Libreria Editrice Vaticana. Stefańki, J. (2005). Caeremoniale Episcoporum. Konspekt historyczny. In R. Biel (Ed.), Ku liturgii nadziei. Księdzu dr. Bolesławowi Margańskiemu w sześćdziesiąta piątą rocznice urodzin (pp. 387-403). Biblios - Wydawnictwo Diecezji Tarnowskiej.

Stefańki, J. (2006). Edycja typiczna Caeremoniale Episcoporum z roku 1984. Prace redakcyjne. In A. J. Offmański \& Z. Kroplewski (Eds.), Ty jesteś kapłanem na wieki (pp. 267-296). Wydział Teologiczny Uniwersytetu Szczecińskiego. 
Stefański, J. (2006). „Caeremoniale Episcoporum” z roku 1984. Prezentacja księgi. Liturgia Sacra. Liturgia - Musica - Ars, 12(2), 223-236.

Tamburini, F., \& Nabuco, J. (1966). Le cérémonial apostolique avant Innocent VIII. Texte du manuscrit Urbinate Latin 469 de la Bibliothèque Vaticane. Edizioni Liturgiche.

Walter, I. (n.d.). Burckard, Johannes. Dizionario Biografico Degli Italiani. Retrieved January 5, 2019, from http://www.treccani.it/enciclopedia/johannes-burckard_(Dizionario -Biografico) 